専門医症例報告

すれ違い咬合による咀嚼障害をオーバーデンチャーにて治療した 1 症例 佐藤奈保子

\title{
A case report on the treatment of mastication disorder resulting from cross bite using an overdenture
}

\author{
Naoko Sato
}

\begin{abstract}
抄 録
症例の概要 : 患者は 64 歳女性. 上顎臼歯部辺縁歯肉の炎症性疼痛と下顎義歯不適合よる咀嚼障害を主訴 に来院した。上顎残存歯補綴装置のマージン部不適合と, 中等度慢性歯周炎による水平的骨吸収のため, 歯冠歯根比の減少が認められた。歯冠歯根比の改善と口腔清掃状態の向上を図るため, 治療義歯を装着し た。将来的に咬合関係に影響を与えにくい設計を考慮し, 最終補綴として磁性アタッチメントオーバーデ ンチャーを選択した。

考察 : 咬合力の分散と歯冠歯根比の改善により，機能時における義歯の安定が図れたものと考える. 結論：すれ違い咬合の治療に磁性アタッチメントオーバーデンチャーを適用し, 長期的に良好な経過が得 られた。
\end{abstract}

和文キーワード

すれ違い咬合，オーバーデンチャー，磁性アタッチメント

\section{ABSTRACT}

Patient: A 64-year-old woman came to our hospital with the chief complaint of inflammatory pain in the marginal gingiva of the maxillary molars and mastication disorder due to ill-fitting mandibular dentures. Ill-fitting margin of the prosthetic device and imbalance of the crown-root ratio were observed. In order to improve the crown-root ratio and oral hygiene, a treatment denture was placed. The magnetic attachment overdenture was selected as the final prosthesis in consideration of a design that would less affect the occlusal relationship in the future.

Discussion: It is considered that the stability of the denture when functioning can be achieved by dispersing the occlusal force and improving the crown-root ratio.

Conclusion: A long-lasting good outcome was obtained by applying the magnetic attachment overdenture for the treatment of cross bite.

\section{Key words}

cross bite, overdenture, magnetic attachment 


\section{I。緒言}

すれ違い咬合は，多様な欠損形態の中でも特異的な存在 であり, 咬合圧の分散が難しく, 義歯の回転沈下が避けら れないため, 義歯装着の䫈位も不安定となる. 加えて残存 歯の挺出, 顎堤吸収の進行, 咬合平面の不整を併発してい ることが多く，全顎的な補綴治療が必要となる。また，残 存歯や顎堤粘膜への過剩な咬合圧が，新たな欠損拡大と顎 堤吸収を引き起こすこともある。 Vermeulen ら ${ }^{1)}$ は，支台 歯をアタッチメントタイプにすると, クラスプを使用した 場合に比べて，再治療率が低くなったと述べている，本症 例では，す机違い咬合症例に対し磁性アタッチメントオー バーデンチャーを選択し，良好な結果が得られたため報告 する。

\section{II. 症例の概要}

患者：64 歳，女性.

初診日：2008年 11 月 26 日.

主訴 : 右上奥歯の歯茎が痛い.下の入れ歯が痛くてうま く咬めない.

全身的既往歴：特記事項なし.

歯科的既往歴：2006 年に左側顎関節のクリック音を主 訴に当院顎関節症診療センターに来院しているが，疼痛は なく, 開口量，画像所見に異常は認められなかった。生活 指導にて自覚症状の改善がみられたため, 治療を終了した。

現病歴：上顎の補綴装置は, 15 年程前に装着されたもの であり，当初は問題なく使用していたが，歯肉からの出血 および疼痛は時折自覚していた。2008 年 2 月には下顎義 歯床下粘膜の疼痛と上顎臼歯部歯肉からの出血を主訴に当 院総合診療科に来院し，インプラントを含めた治療計画を 提案されたが，通院が途絶えていた。

現症：

全身所見：特記事項なし。

口腔内所見：上顎臼歯部は全部金属冠で補綴されていた が，マージン部に不適合が認められた（図 1)，76 煩側歯 肉は, 腫脹とプロービング時の排膿が認められた。初診時 X 線所見では, 764 に歯根長の $1 / 2$ を超える水平的骨吸収が 認められた。76に 2 3 mm の根尖部透過像か認められ た（図 2). 初診時歯周精密検査にて, 全顎的に $4 \mathrm{~mm}$ 以上 のプロービングデプスと, プロービング時の出血が認められ た. 76 および 6 に Lindhe と Nyman の分類 1 度の分岐部 病変が認められた（図 3)。装着されていた下顎局部床義歯 は, すれ違い咬合のため機能時に過度の義歯床沈下を生じ, 床下粘膜疼痛による咀嚼困難を引き起こしていた。

診断：すれ違い咬合による咀嚼障害および中等度慢性歯 周炎と診断した。

Kennedyの分類は上顎が class IV, 下顎が class I, Eichnerの分類は $\mathrm{Cl}$, 咬合三角は第 3 エリア, 日本補綴 歯科学会の症例分類は level IIIであった.
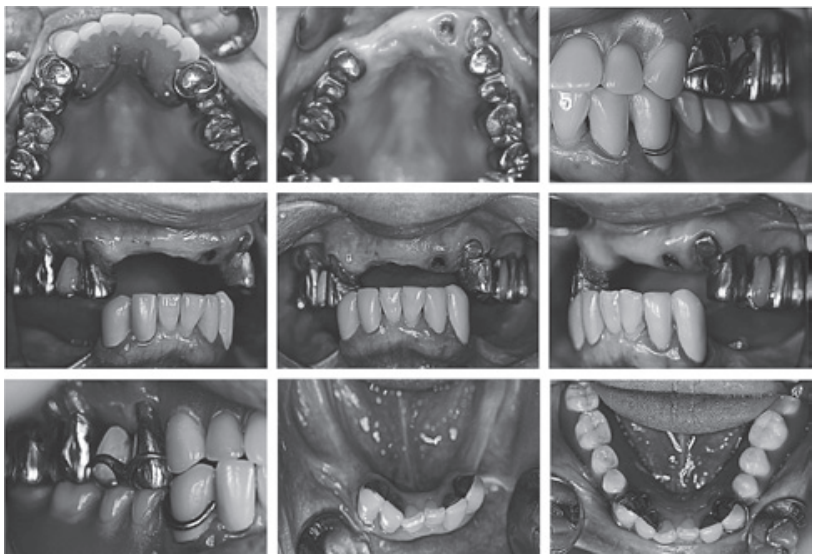

図 1 Intraoral views at the first visit 初診時口腔内写真

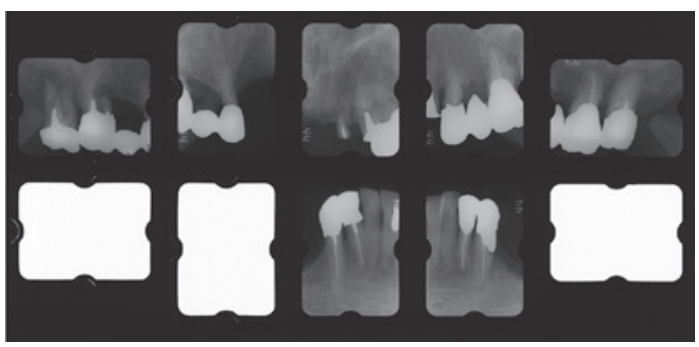

図 2 Dental radiographs at the first visit 初診時デンタル X 線写真

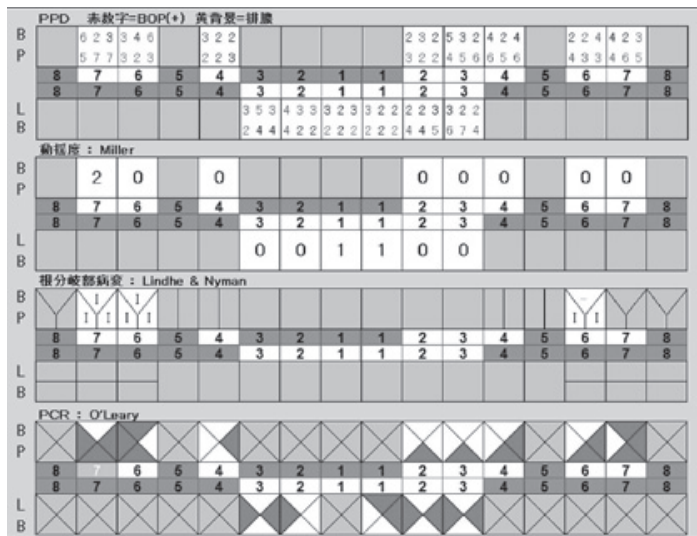

図 3 Periodontal condition at first examination 初診時歯周組織検査

\section{III． 治療内容と経過}

治療方針および計画：選択できる補綴治療計画として, 歯冠補綴装置とクラスプ義歯による方法, 各種オーバーデ ンチャーによる方法, 保存不可能な歯を抜歯し, インプラ ントを併用した方法を挙げた。患者は可能な限り残存歯の 保存を希望した。患者の希望を考慮し, かつ長期的に安定 した咬合状態を維持し, 残存歯のトラブルに対応しやすい 補綴装置の選択が必要であった。残存歯の歯冠歯根比を改 


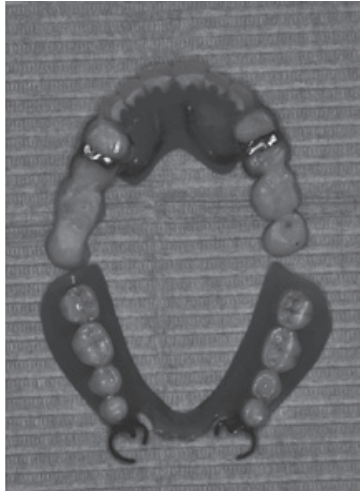

図 4 The existing denture which was repaired 修理した旧義歯
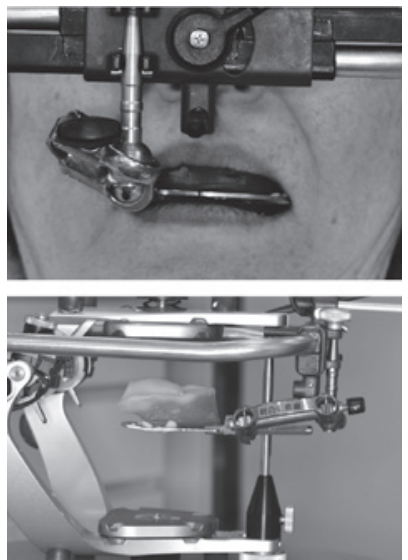

図 6 Facebow transfer フェイスボウトランス ファー
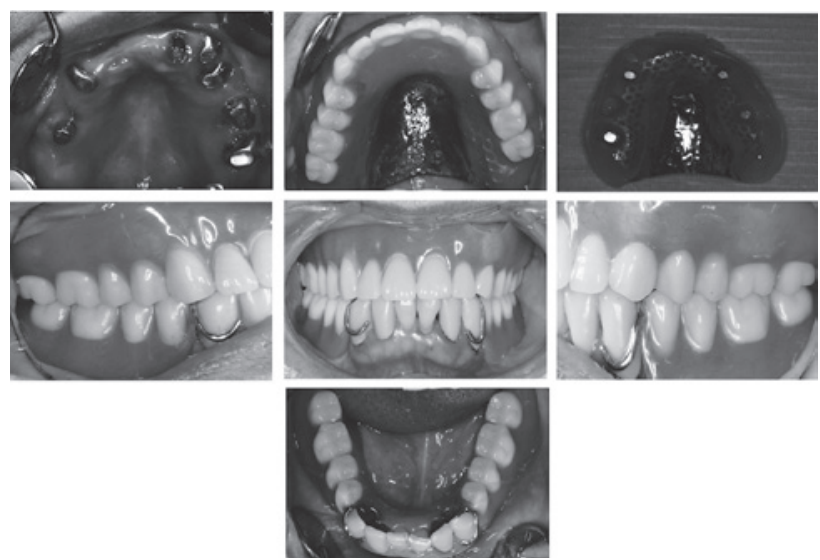

図 8 Intraoral views at the insertion definitive prosthesis 最終補綴装置装着時

善できること，残存歯のトラブルに対応しやすいこと，患 者自身での清掃性，操作性に優れていること，これらを 満たす補綴設計として磁性アタッチメントオーバーデン チャーを選択した。患者は提案した治療計画を理解し同意 したため，治療を開始した。
治療内容：歯周基本治療を開始し，ブラッシング指導に より口腔衛生状態の改善を図った。上顎残存歯の歯冠歯根 比の改善と清掃性の向上を図るため，不適合補綴装置を除 去し，旧義歯の改造を行った（図 4)。歯周治療を続けなが ら最終補綴装置の形態への適応能力，義歯の回転沈下の度 合いを確認するため，治療義歯を製作した（図 5)，咬合採 得は顔面計測法を利用した。治療義歯の受け入れはスムー ズで安定していたため，残存歯の処置へ移行した。歯周基 本治療終了時点において保存不可能と診断した 6 近心煩側

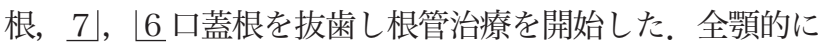
プロービングデプスが $4 \mathrm{~mm}$ 以内となった 2010 年 10 月 に根面板の精密印象を行った。磁石構造体の設置部位は, 歯根分割歯を避け 4$\rfloor ， 47$ とした。根面板は金合金にて製 作した。続いて上下義歯の精密印象採得を行った。個人卜 レー, 筋圧形成用コンパウンド（イソコンパウンド， GC, 東京, 日本), 口腔内粘膜印象用親水性ビニルシリコーン印 象材 (エグザデンチャー, GC, 東京, 日本) にて行った。フェ イスボウトランスファーを行い，治療義歯に準じて垂直的 顎間関係を決定した（図 6)。ゴシックアーチ描記法にて水 平的顎間関係を決定した。タッピングポイントはアペック スよりわずかに前方に位置していたが，安定して集束した ためタッピングポイントで決定した（図 7)。メタルフレー ムにはコバルトクロム合金を使用し，咬合様式は両側性平 衡咬合を付与した。磁石構造体は, サンドブラスト処理, プライマー処理後, 口腔内で義歯内面に装着した。磁石構 造体を義歯に取り込んだ後，根面板軸面周囲のレジンを一 層削合することで側方力を軽減した（図 8).

3 力月に 1 度機械的歯面清掃と咬合状態の確認を行って いる.X線所見において 4、に歯根膜腔の拡大がみられるが, 残存歯の歯周ポケットの梁化や床下粘膜の疼痛，義歯の破 損はなく，咬合状態も安定している（図 9，10，11）。

\section{IV. 考 察}

すれ違い咬合症例において，歯牙接触がなく，顎位を上 下顎に装着された義歯で保持するという条件はシングルデ ンチャーと同様であるが，補綴装置の安定性という点にお いては全く様相を異にし，義歯の沈下，咬合圧の分散が難 しく，それに支持される顎位も不安定となる。義歯の回転 沈下を支台装置で防止しようとすると，義歯破折のトラブ ルが増加する．宮地 ${ }^{2)}$ は，治療上トラブルが頻発する難症 例は, 咀嚼不満足者率の最も高い $14 \pm 4$ 歯の範囲に集中す るとし，この中には咬合支持が 4 か所以下で臨床的対応の 困難な，いわゆるす机違い咬合症例が存在すると述べてい る. 本症例では，中等度慢性歯周炎による歯肉の疼痛と下 顎局部床義歯の沈下による義歯床下粘膜の疼痛により, 咀 嚼障害を生じていた。そこで，すれ違い咬合による受圧因 子と, 中等度慢性歯周炎に罹患した歯牙の長期経過時の再 補綴の必要性を考慮し, 磁性アタッチメントオーバーデン チャーを選択した．上顎をオーバーデンチャーとしたこと 

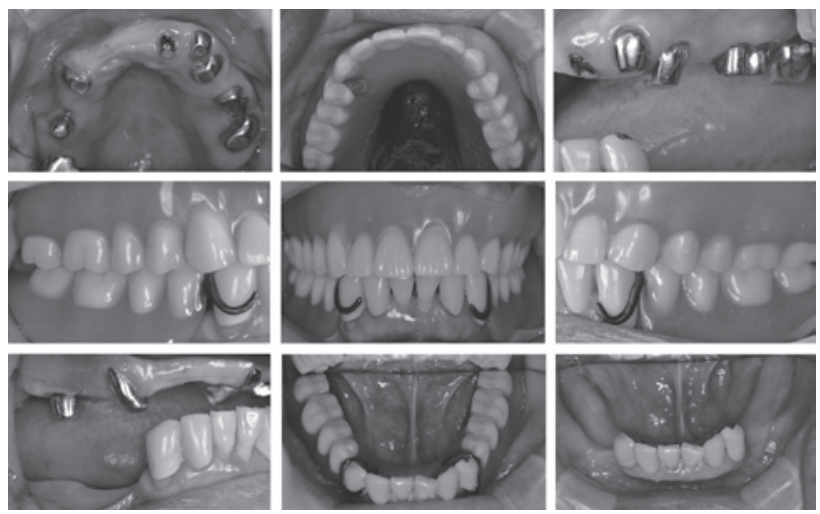

図 9 Intraoral views at 3 years after prosthetic treatment 3 年経過時口腔内写真

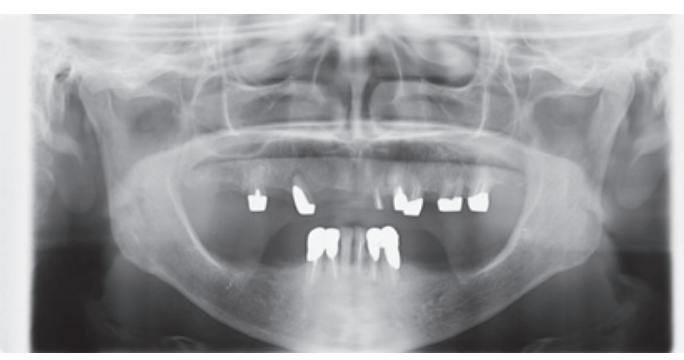

図 10 Panoramic radiography at 3 years after prosthetic treatment

3 年経過時パノラマX 線写真
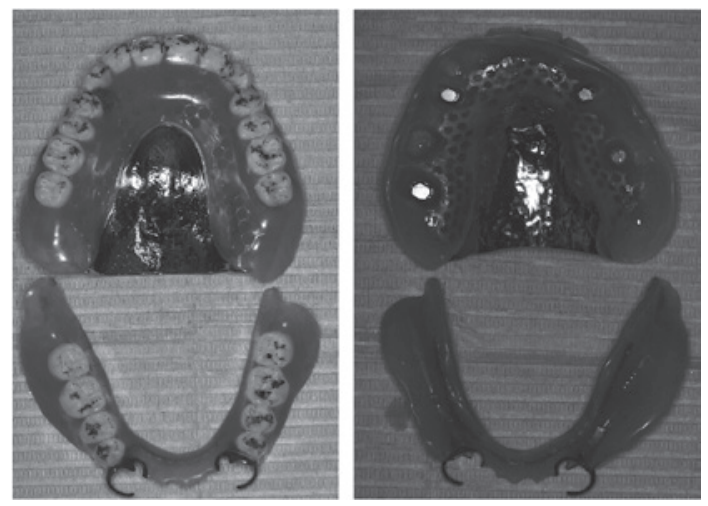

図 11 Final prostheses at 3 years after prosthetic treatment

3 年経過時最終補経装置

で，咬合平面の修正と咬合圧の分散が図れ，下顎臼歯部の 義歯床の沈下が抑えられ, 義歯床下粘膜の疼痛が軽減した ものと考える。 また田中 ${ }^{3)}$ は, 磁性アタッチメントは長期 経過時の維持力の減衰がなく, 維持力は磁石構造体が根面 板から離れると急激に減少するため，義歯の着脱時に支台 歯に非機能的な力が加わる危険性が少ないと述べている. 骨植の不良な支台歯において磁性アタッチメントを使用す ることは非常に有用であると考える。
本症例ではさらなる側方力の軽減のため, 根面板部の義 歯床内面は完成後に削合したが, 3 年経過後のパノラマX 線写真において 4 」歯根膜腔の拡大がみられた。根面板の 高さが支台歯に及ぼす影響についての研究において, 藤本 ${ }^{4)}$ らは，支台歯の近遠心方向にはほとんど変化がみられない のに対し, 煩舌方向の変位量は根面板の高さが増すほど増 加すると述べている. また, 根面板上面の傾斜角度が支台 歯に及ぼす影響に関する研究において，片倉 ${ }^{5)} ら は ，$ 根面 板上面の傾斜角度を歯軸と垂直にすることで応力集中の範 囲は小さくなると述べている。4」は, 最終補綴装置の人工 歯の犬歯部に位置していた。両側性平衡咬合を付与しては いるものの, 下顎残存歯の存在から過度の側方力が加わっ ていた可能性は否定できない. 根面板の傾斜角度を犬歯に 類似させる必要性があったかもしれない，現在まで，義歯 粘膜面の適合は良好であり義歯床の破損等は生じていない が, 今後も義歯粘膜面の適合状態や咬合状態の確認を定期 的に行っていく必要があると考える.

\section{$\mathrm{V}$. 結 論}

すれ違い咬合の治療に磁性アタッチメントオーバーデン チャーを使用した。その結果, 上顎残存歯の保存と下顎義 歯床下粘膜の疼痛による咀嚼障害の改善が図れ, 長期的に 良好な経過が得られた。

\section{文献}

1) Vermeulen AH. Ten-year evaluation of removable partial dentures: survival rates based on retreatment, not wearing and replacement. J Prosthet Dent 1996; 76: 267-272.

2）宮地建夫。 症例でみる欠損歯列・ 欠損補綴 レベル・パ ターン・スピード. 東京 : 医歯薬出版；2011，16-20.

3）田中貴信. 磁性アタッチメント 磁石を利用した新しい 補綴治療法。東京：医歯薬出版；1992，29-39.

4）藤本俊輝, 石上友彦, 大谷賢二, 大山哲生, 澤野宗如, 高村昌明ほか. キーパー根面板の高さがオーバーデン チャーの支台歯に及ぼす影響。日磁歯誌 $2006 ； 15(1)$ ： 29-34.

5）片倉祐輔, 大山哲生, 石上友彦, 永井栄一, 山中大輔, 小豆烟拓夫ほか. オーバーデンチャーにおける支台歯根 面板上面の傾斜角度の違いが周囲皮質骨に及ぼす影響. 日磁歯誌 $2009 ； 18(1)$ : 19-24.

\footnotetext{
著者連絡先：佐藤奈保子

于 102-8158 東京都千代田区富士見 2-3-16 日本歯科大学附属病院総合診療科

Tel: 03-3261-5511

Fax: 03-3261-5743

E-mail: sato-n@tky.ndu.ac.jp
} 